УДК 783.087:274/278(091)
DOІ https://doi.org/10.31723/2524-0447-2021-32-1-9

\author{
Ярослав Володимирович Петреску \\ ORCID: 0000-0002-5858-8404 \\ викладач кафедри хореографіі \\ та музично-інструментального виконавства \\ Сумського державного педагогічного університету \\ імені А. С. Макаренка \\ ja.petresky@gmail.com
}

\title{
ЖАНРИ ДУХОВНОЇ МУЗИКИ ПРОТЕСТАНТСЬКИХ ЦЕРКОВ
}

\begin{abstract}
Мета роботи - визначити основні жанри духовної музики протестантизму, особливості їх зародження та функціонування в різних конфесіях, проаналізувати сучасний стан музики в євангельських иерквах України. Методологія дослідження є комплексною і спирається на історико-типологічний метод (у аналізі історичних зв'язків формування женрів духовної музики різних протестантських конфесій), метод герменевтики (у тлумаченні доктринальних особливостей творів), метод музично-теоретичного аналізу (у виявленні гармонійних, мелодичних та формоутворювальних елементів творів), компаративний метод (у порівнянні жканрів иерковної музики) та метод узагальнення (у підбитті підсумків дослідження). Наукова новизна. Духовна музика протестантської церкви вперше розглянута з точки зору історичної ретроспективи їі жанрової системи. Коротко охарактеризовано провідні жканри католицької та православної церковної музики, як-от григоріанський хорал, меса, літургія, знаменний розспів, партесні та хорові кониерти; проаналізовано мотети Й. Вальтера, Л. Зенфля, духовні твори Г. Шютиа та Й. С. Баха (Страсті, кантати); розалянуто історичний шлях появи протестантів на території сучасної України та їх внесок у становлення російської духовної пісні Івана Проханова. У висновках зазначено, що духовна музика протестантських церков вирізняється неймовірним розмаїттям жанрів та стилів, а основою жанрової системи музики сучасних євангельських християн є общинний та хоровий спів - хорали XVI-XVII століть, твори композиторів-класиків, духовні nісні сучасних авторів, джазово-естрадні обробки. Окрім цього, у протестантських церквах активно застосовується інструментальна музика (орган, фортепіано, камерні, духові, симфонічні оркестри, сучасні естрадні гурти).
\end{abstract}

Ключові слова: протестантська церква, жанр, духовна музика, хорал, мотет, гімн, псалом, антем, музичні інструменти, орган.

(C) Петреску Я. В., 2021 
Petresku Yaroslav Volodymyrovych, Lecturer at the Department of Choreography and Music-Instrumental Performance of the Sumy State Pedagogical University named after A. S. Makarenko

Genres of sacred music of Protestant churches

Research objective - to determine the main genres of spiritual music of Protestantism, the peculiarities of their origin and functioning in different denominations, the current state of music in the Christian evangelical churches of Ukraine. The methodology is complex and based on the historicaltypological methods in the process of revealing historical connections of origin and formation of genres of spiritual music of different Protestant denominations, the method of hermeneutics in interpreting doctrinal features of works, the method of music-theoretical analysis in identifying harmonic, melodic and formative elements. on the comparative method when comparing the results and the method of generalization - when summarizing the results of the study. The scientific novelty. For the first time the spiritual music of the Protestant church is considered from the point of view of the historical retrospective of its genre system. The leading genres of Catholic and Orthodox church music are briefly described - Gregorian chant, Mass, liturgy, significant chant, party and choral concerts, motets by J. Walter, L. Zenfl, spiritual works by G. Schutz and J. S. Bach - Passions, Kantates. The historical way of appearance of Protestants on the territory of modern Ukraine and the contribution to the formation of Russian spiritual song by Ivan Prokhanov are considered. Conclusions. The spiritual music of Protestant churches is characterized by an incredible variety of genres and styles, and the basis of the genre system of evangelical Christian music today is communal and choral singing chorales of XVI-XVII centuries, works of classical composers, spiritual songs of modern authors, jazz and pop processing. In addition, Protestant churches actively use instrumental music - organ, piano, chamber, brass, symphony orchestras, modern pop groups.

Key words: Protestant church, genre, spiritual music, chorale, motet, hymn, psalm, anthem, musical instruments, organ.

Актуальність теми дослідження. Духовна музика другої за чисельністю прибічників гілки християнства - протестантизму - це яскрава та різнобарвна сторінка світового музичного доробку. Як і основоположник руху духовної Реформації Мартин Лютер, більшість протестантів мають великий пієтет до музики та використовують iї як дієвий засіб висловлення хвали та подяки Творцеві. Зараз вокальна сфера в церквах представлена надзвичайно великим репертуаром общинного співу: від хоралів Лютера та інших митців XVI-XVII століть до пісень американських та вітчизняних сучасних авторів. Загальний спів у церквах лунає як без супроводу, так і під акомпанемент органа, фортепіано чи гурту музикантів. Значне місце належить хоровому жанру, який набув особливого 
розквіту на наших землях за радянських часів. Хорові колективи є майже в усіх традиційних церквах християн-баптистів, п’ятдесятників, адвентистів сьомого дня. Деякі новітні течії протестантизму, що виникли у XX столітті, віддають перевагу естрадній групі з ансамблем співаків.

Інструментальна музика також використовується майже в усіх протестантських церквах. У лютеран та кальвіністів (реформаторів, пресвітеріан, тощо) - це майже завжди орган, у більш пізніх євангельських християн - оркестри та гурти джазового чи естрадного складу, які використовуються не лише на свята, а й під час щонедільних служб.

Про роль та значення Реформації у духовному житті Європи (а згодом і всього світу) є чимало робіт релігієзнавців, істориків, філософів. Важливими в контексті цієї теми $є$ статті Г. Хоружого «Протестантизм як результат європейської Реформації» [17], М. Черенкова «Протестантская теология и философия религии: встречи на границах иного» [18], В. Кадочникова «Музыка протестантских церквей в поисках образа Христа» [7], монографія Е. Уілсон-Діксона «История христианской музики» [16].

Стрімкий розвиток протестантської музики зумовлює підвищення інтересу дослідників до аналізу цієї сфери. В Україні цим займається низка науковців, а саме: І. Бондар досліджує «Особливості вияву духовної традиції лютеранствав музичному мистецтві Західної Європи» [1], витоки та процес становлення церковної музики аналізує О. Ярош у статті «Протестантська сакральна музика: духовні основи і витоки формування традиції [19], а сучасний стан музики вивчає О. Спис («Сучасна протестантська пісенно-музична творчість як форма служіння: проблеми і виклики») [15]. Проте питання жанрової системи духовних творів протестантизму порушувалося в наведених роботах лише частково, тому потребує додаткового опрацювання, що зумовлює актуальність цієї роботи.

Мета дослідження - визначити основні жанри духовної музики протестантизму, особливості їх зародження та функціонування в різних конфесіях, сучасний стан музики в християнських євангельських церквах України.

Наукова новизна. Духовна музика протестантської церкви вперше розглянута з точки зору історичної ретроспективи іiі жанрової системи. Коротко охарактеризовано провідні жанри католицької та православної церковної музики, як-от григорі- 
анський хорал, меса, літургія, знаменний розспів, партесні та хорові концерти; проаналізовано мотети И. Вальтера, Л. Зенфля, духовні твори Г. Шютца та Й. С. Баха (Страсті, кантати). Розглянуто історичний шлях появи протестантів на території сучасної України та внесок у становлення російської духовної пісні Івана Проханова.

Виклад основного матеріалу. 3 часів виникнення і дотепер християнство вирізняється 3-поміж інших світових релігій надзвичайно великим значенням, яке відводиться в богослужінні музичному мистецтву. Розмаїтою $є$ система жанрів та стилів церковної музики, а обсяг та якість духовного музичного доробку просто вражає. Сміливо можна стверджувати, що шлях розвитку класичної європейської музики розпочався саме в церковних стінах, бо першими професійними композиторами, співаками та музикантами були монахи й служителі католицької церкви. Після розколу християнства в XI ст. та виникнення православної церкви музика західного та східного обряду розвивалася власними шляхами.

Першим духовним жанром вважається григоріанський xорал - спів католицької церкви, сформований та канонізований папою Григорієм I на межі VI-VII ст. Ці неспішні унісонні наспіви стали основою, на якій пізніше виросли перші зразки багатоголосся - органум та дискант, а згодом «розквітла» ренесансна поліфонія. За способом виконання григоріанський спів розділявся на антифонний та респонсорний. Антифоном, тобто співом по черзі двох хорів чи хорових груп, як правило, виконувалися псалми, а респонсорій застосовувався для своєрідних музичних «діалогів» між солістом (часто священиком) та хором.

Розвиток церковної музики привів до появи нових піснеспівів - секвенцій, троп, кондуктів та різноманітних обробок хоралів у техніці cantus firmus. В епоху Середньовіччя формується основний жанр богослужбової музики - меса, що містив низку обов'язкових частин (Ordinarium) та розділів, що змінювалися відповідно свята чи події (Proprium).

Шодо використання музичних інструментів, то першим церковним інструментом був орган, який увів у богослужіння папа Римський Віталіан ще у VII столітті. Згодом орган супроводжував виконання меси, а на Тридентському coборі у XVI столітті було офіційно затверджено та визначено функції інструмента, серед яких основні - дублювання 
хорових партій, а також виконання сольних інструментальних епізодів (токат, річеркарів, канцонів тощо). Поступово католицька церква дозволила використання й інших інструментів, зокрема, струнних та дерев'яних духових, але переважно не під час меси, а у позаслужбових духовних концертах.

Православна церковна традиція сформувала власну строго вокальну месу - літургію та й досі не визнає участі в ній будь-яких інструментів. Одноголосні наспіви, що здавна супроводжували службу у Візантії, були засновані на системі осмогласся, чи восьмигласся, - восьми особливих літургійних ладів (по одному на тиждень). Іоанн Дамаскін у VIII столітті впорядкував цю систему у вигляді богослужбової книги Октоїха. В межах осьмогласся приблизно з ХІІ столітті формується знаменний розспів, різновидами якого є київський, грецький, болгарський розспіви та інші. В Україні-Русі одноголосний знаменний розспів змінив партесний багатоголосний спів, що набув особливого розквіту в XVII столітті, коли з'явилися партесні концерти М. Дилецького, I. Домарацького, С. Пекалицького та інших. До виконання партесних творів залучалися лише хлопчики та чоловіки. Ще пізніше, у другій половині наступного століття, розлогі, циклічні хорові концерти М. Березовського, Д. Бортнянського та А. Веделя витіснили партес. Ці унікальні твори стали результатом органічного синтезу культури партесного співу, досягнень західноєвропейського класицизму та інтонацій української народної пісенності.

Незважаючи на великий історичний шлях та вагомість досягнень у сфері духовної музики композиторів католицької та православної церков, найбільш «співочою» та музикальною християнською конфесією можна назвати протестантизм. Небачені свобода творчості та право на тлумачення біблійних текстів, які запропонував вірянам основоположник руху Мартин Лютер, а також нагальна потреба в оновленні літургійного репертуару стали потужним стимулом бурхливого розквіту церковної музики.

Реформація розпочалася в Німеччині у XVI столітті, хоча передумови їі виникнення та ареал розповсюдження охоплюють значно ширший як часовий, так і географічний простір. Протест Лютера проти зловживань католицької церкви й мертвості іiі структури був швидко підхоплений невдоволеним народом та фактично розділив його на два табори. Звісно, 
до суто релігійних питань приєдналися політичні та економічні інтереси, але єдність західноєвропейської церкви була назавжди порушена.

Фактично з періоду свого зародження і протягом усього подальшого історичного шляху протестантизм не був єдиною церквою з унітарною системою управління та богословськими догматами. Хоча ціла низка поглядів та аспектів віровчення є спільними для всіх протестантських течій. Серед них основні - це невизнання жодних посередників між Богом та людьми, окрім Христа, відмова від поклоніння святим, пишності служби та ікон. Основною доктриною є спасіння за благодаттю, лише вірою, а не завдяки добрим справам чи іншим заслугам. Більшість церков визнає лише два таїнства - хрещення та причастя.

Суттєво різниться і музичне оформлення богослужінь. Оскільки основними течіями раннього протестантизму були лютеранство, кальвінізм і англіканство, розглянемо головні музичні жанри цих напрямів.

Фундатор лютеранської церкви Мартин Лютер (1483-1546) був також автором іiі перших духовних творів - протестантських хоралів. Він обрав та переробив кілька відомих на той час католицьких гімнів та світських, народних пісень, підтекстувавши їх рідною німецькою мовою‥ Кілька хоралів є оригінальними роботами Лютера, а його найвідомішим гімном став «Ein feste Burg ist unser Gott» («Господь наш - оплот»). Утім найбільшим досягненням реформатора вважається відновлення загального співу, участь у літургії не кількох обраних осіб, а всієї громади. Починаючи з 1526 року, Лютер запровадив загальні общинні репетиції на тижні для вивчення нових пісень і навіть на певний час розпустив хор. Згодом він усе ж не відмовився від співу професійного колективу, а літургія складалася з виконання нескладних хоралів усією общиною, що чергувалися з хоровими поліфонічними творами.

Маючи гарну музичну освіту, Лютер розумів, який величезний вплив має музика на серця людей та їхні емоції, саме тому він відводив їй особливе місце: «Поруч із проповідуванням Священного Писання я ставлю музику на найвище місце

1 Слід зауважити, що Лютер ретельно обирав народні пісні для переробки. По-перше, ці пісні мали бути добре відомими людям, щоб їм не доводилося вчити разом із новими словами ще й мелодію. По-друге, обрані пісні не повинні мати жодних негативних асоціацій. 
в церкві. Я хочу, щоб слово Боже пробувало в серцях вірян за допомогою пісні. $Є$ тональна єдність музики і богослов'я. Музика огорнена богослов'ям і зачинена в ньому. Я не дозволив би жодній людині проповідувати або вчити людей Божих тому, хто не зрозумів сили і використання духовної музики» [цит. за: 6, с. 139].

Навколо Лютера об'єдналося декілька талановитих композиторів, які також писали духовні твори для молодої церкви. Одним із них був Йоганн Вальтер (1496-1570 - поет, композитор, перший кантор протестантської церкви, близький друг Лютера. У творчій співпраці вони опублікували кілька важливих збірок церковних піснеспівів, як-от «Віттенберзький пісенник» (1524), «Німецька меса та порядок поклоніння» (1526) та інші.

Основним жанром, у якому працював Й. Вальтер, був мотет - жанр поліфонічної вокальної музики, відомий із XII століття. Свої мотети він створював під впливом композиторів франко-фламандської школи, зокрема Жоскена де Пре. Основою твору слугувала мелодія хоралу, яку він опрацьовував у техніці cantus firmus. Згідно з домінантною тоді традицією композитор розташовував тему хоралу переважно в теноровому голосі, тоді як інші голоси огортали іiі барвистими контрапунктичними лініями. Прикладом такого типу обробки є ніжнийі стриманий мотет «Ach Gott vom himmel» («О, Боже небесний»).

Утім Й. Вальтер працював і в іншому стилі, розміщуючи мелодію хоралу у верхньому голосі, оскільки так тему було краще чути, що уможливлювало іiі спів усією громадою. Таким є його урочистий мотет «Komm, Gott Schupfer» («Прийди, Бог Творець») на основі хоралу Лютера, викладеного в партії сопрано. Канонічні імітації в інших голосах підкреслюють піднесений настрій твору.

Високоякісні духовні мотети писав для лютеранської церкви i один із найвідоміших композиторів тогочасної Німеччини, придворний капельмейстер у Мюнхені Людвіг Зенфль (1492-1542). Він працював у жанрі пісенного мотету - Liedmotette, яких у нього близько 250, та писав твори як німецькою мовою, так і латиною. Популярністю користуються його мотети «Nisi Dominus» («Тільки Господь»), «Veni Sancte Spiritus» («Прийди, Святий Дух»), «Non moriar, sed vivam» («Не вмирай, а живи»). 
Кульмінацією процесу обробки протестантських хоралів $€$ творчість німців Генріха Шютца (1585-1672) та Йоганна Себастьяна Баха (1685-1750). Обидва відомі композитори були людьми глибоко віруючими та свою творчість присвячували винятково Богові. Саме вони затвердили розуміння церковної музики не лише як засобу поклоніння, а як своєрідної проповіді та чудового способу тлумачення Святого Письма. Про музику Шютца дослідник Пауль Піск сказав так: «Його музика живе тільки у зв'язку зі словом, яке вона підсилює. Це слово - Слово Боже. Шютц молиться, сповідається і проповідує у своїй музиці» [цит. за: 6, с. 160].

Учителями Г. Шютца були видатні італійські митці Джованні Габріелі та Клаудіо Монтеверді, вплив яких є найбільш очевидним у його мадригалах. Популярні на той час італійські прийоми письма, як-от музична риторика, техніка basso ostinato (незмінний бас) та інші, втілилися у його двох томах «Маленьких духовних концертів», виданих у 1636 та 1639 роках. I Шютц, і Бах працювали у жанрі Cmрастей великих вокально-інструментальних творів на сюжет останніх днів життя Христа на землі, його розп'яття та воскресіння.

Одним із центральних жанрів у духовному доробку Й. С. Баха є кантата, яких збереглося більше двохсот опусів, більшість із них цілком або своїми окремими частинами засновані на хоралах. Кантати написані переважно на біблійні тексти та приурочені для виконання під час або після недільних служб. Виконавський склад - кілька співаків-солістів, хор та оркестр, який для кожної кантати підбирався окремо. Надзвичайно різняться твори за композиційною логікою, характером та жанровими різновидами: ліричні, героїко-епічні, філософські чи святково-урочисті кантати.

Якшо композитори-лютерани в перші століття після Реформації активно працювали у декількох жанрах та розвивали інструментальну церковну музику, то послідовники У. Цвінглі та Ж. Кальвіна у Швейцарії, Франції, Угорщині та інших країнах Європи віддавали перевагу жанру псалма. Мелодичні перекладення Псалтиря виконувалися в унісон усією общиною, а також слугували основою для багатоголосних хорових обробок. Псалми вирізнялися силабічною мелодикою, відсутністю розспівів та антифонним викладом.

Значний внесок у розвиток протестантської духовної музики зроблено митцями англіканської церкви. Найяскраві- 
шим жанром у XVI-XVII століттях був антем - багатоголосний хоровий твір (часто з інструментальним супроводом) англійською мовою на біблійний текст. Існувало два основних різновиди - так званий full anthem (повний антем), хоровий твір a cappella або зі стриманим органним акомпанементом, та verse anthem (строфічний антем), у якому сольні розділи чергуються 3 хоровими. Другий різновид передбачав також інструментальний супровід органу, струнних та (в особливо урочисті моменти) духових інструментів.

Перехід від суто біблійної псалмової текстової основи духовних творів до власних поетичних рядків пов'язаний насамперед із діяльністю Ісаака Уоттса (1674-1748), якого називають «батьком англійських гімнів». Відвідуючи разом із родиною англіканську церкву, він рано почав перейматися станом общинного співу та якістю гімнів, псалмові тексти яких часто були недовершеними та незручними для співу. Засмучений юнак вирішив спробувати написати власний гімн, який був сприйнятий прихожанами з великим ентузіазмом. Протягом кількох наступних років І. Уоттс щонеділі писав новий гімн, деякі з яких становили метричні версії псалмів, а інші - відображення його суб'єктивного бачення та духовного досвіду. Всього ним створено більше 500 гімнів, деякі з яких виконуються в християнських церквах і донині, як-от святкова різдвяна пісня «Јоу to the world» («Земле, радій!») та «When I Survey The Wondrous Cross» («Коли я споглядаю чудовий хрест»). Діяльність І. Уоттса за його життя викликала суперечливі оцінки. Його часто критикували за відхід від біблійної основи текстів, на що поет відповідав: «Якщо ми можемо молитися Богові реченнями, які ми складаємо самі (замість того, щоб обмежувати себе молитвою «Отче наш» та іншими молитвами, безпосередньо взятими з Писання), то, звичайно ж, ми можемо співати Богові реченнями, які ми складаємо самі» [цит. за: 6, с. 190].

Досить швидко новий християнський напрям у вигляді таких конфесій, як лютерани, меноніти, реформатори, пресвітеріани та інші, не лише поширився країнами Європи, а й став домінантним у США, деяких країнах Азії та Африки. В Україні перші протестантські церкви з'явилися у XVII столітті на Волині у вигляді спільнот анабаптистів («перехрещенців») - вірян, які не приймали хрещення немовлят, а розглядали цей акт лише як свідомий вибір дорослої людини. 
Розвиток протестантизму в XIX столітті приводить до виникнення на наших землях низки більш пізніх євангельських конфесій, серед яких найчисельнішими є це баптисти, п'ятдесятники, євангелісти, адвентисти, методисти тощо. За певних доктринальних та організаційних відмінностей більшість цих церков поділяє спільні віросповідні принципи, здійснює два таїнства - хрещення і причастя. Основною умовою спасіння є глибока особиста віра та надія на благодать Божу. Схожою є структура богослужіння, яке проводиться національною мовою і складається 3 проповідей, загальної молитви і музичної частини.

Нині церковна музика кожної окремої конфесії має свої особливості, тому зупинимося на історії формування репертуару сучасного загального співу євангельських християн-баптистів як одного з найчисельніших об’єднань. В Україні існує понад 2500 общин, які щонеділі відвідують 300000 осіб, а також у межах союзу ЕХБ діють 15 вищих навчальних закладів та 39 закладів середньої духовної освіти, серед яких кілька надають і музичну освіту [11].

Історія свідчить про те, що першою баптистською громадою була церква в с. Карлівка (сучасна Кіровоградщина), яку в 1869 році організував німець-колоніст А. Унгер, а сама назва конфесії походить від грецького «baptize» - «хрестити». Згодом такі общини поширилися територією Російської імпеpiї та західних областей України. На початку XX століття баптистські спільноти розпочали зближення з євангелістами, які були їм надзвичайно близькими за віровченням. 1908 року відбувся з’їз євангелістів у Катеринославі, на якому було утворено Всеросійський союз євангельських християн на чолі 3 І. Прохановим. 1944 року, внаслідок об'єднання баптистів з євангелістами та частиною громад п'ятдесятників, утворено Всесоюзну раду євангельських християн-баптистів. 1947 року до ЄХБ приєдналися християни в дусі апостольському, а в 1963 р. - меноніти.

Музична частина богослужінь складається з двох основних частин - співу усієї громади та хорового виконання. Якщо церква кількісно невелика, то хор замінюється ансамблем співаків. Стиль духовних пісень євангельських християн, який домінує в ортодоксальних церквах сьогодні, багато в чому склався завдяки творчій та організаційній роботі Івана Степановича Проханова (1869-1935) - російського богослова, про- 
повідника, поета та композитора. Через загрозу арешту Іван Степанович певний час провів за кордоном, де отримав гарну загальну та богословську освіту. Після повернення до Росії кілька років був в ув'язнені за активну участь у роботі союзу християн, а у 1928 році, від'їхавши у церковних справах до Канади, більше на Батьківщину не повернувся.

1902 рік уважається роком народження російської духовної nicнi, бо саме тоді вийшла перша збірка гімнів переважно для загально-церковного співу «Гуслі». Назва збірки кореспондує з біблійною книгою «Псалтир», бо обидва слова означають струнно-щипкові інструменти. Підготовкою, редакцією та публікацією видання займався особисто I. Проханов, обравши 506 пісень, із яких 180 були новими, щойно створеними ним самим або його помічниками, а інші - передруковані з попередніх пісенників. Є. Гончаренко справедливо зазначає: «Іван Проханов розглядав духовні піснеспіви як важливу частину церковного богослужіння і як один із головних компонентів формування конфесійної ідентичності. Під час створення псалмів він приділяв велику увагу як змісту тексту, так і самій мелодії. 3 одного боку, Проханов прагнув до використання кращих зразків іноземної церковної музики, з іншого - до створення оригінального стилю, що поєднує радість євангельської звістки і російську національну музичну традицію. До музичного оформлення він залучав євангельських композиторів А. Кеше, Н. Казакова, Г. Драненко. Для забезпечення високого рівня псалмів при союзі була створена спеціальна комісія, куди увійшли люди з вищою музично-теоретичною освітою. Творча праця Івана Проханова сприяла появі нового напряму духовної російської музики» [3, с. 262].

Пізніше на основі збірки «Гуслі» та інших у 1924 році було видано десятизбірку «Духовні пісні», яка також отримала надзвичайну популярність серед євангельських церков. На зміну цьому грунтовному виданню прийшла не менш популярна збірка гімнів «Пісня відродження», вперше видана 1978 року союзом нереєстрованих баптистів. Нова редакція збірки видана 2002 року у двох варіантах: це 800 оновлених пісень у вигляді текстів для загального співу та окремо у вигляді нот для хорового чотириголосся.

Висновки. Таким чином, основу репертуару сучасного общинного співу євангельських християн-баптистів станов- 
лять лютеранські піснеспіви, пісні, написані I. Прохановим або перекладені ним з інших мов, гімни, складені іншими вірянами впродовж XX-XXI століть. Приблизно з 1980-х років органний супровід цих пісень витіснило звучання фортепіано, інколи гітар та ритм-групи. Загалом, «якщо в минулому баптисти уникали світської інформації, прагнули замкнути себе у сфері релігійних інтересів, то тепер вони відкриті світській культурі, внутрішньому та міжнародному життю країни. У поведінці й способі життя значна частина вірян орієнтуються на загальнолюдські цінності та моральні норми, в них переважає світська мотивація прийнятих рішень і поведінки. Зростає миротворча діяльність баптистських громад і участь у ній вірян» [11].

Ця відкритість світській культурі, невідставання від сучасних естрадних стилів, що стало особливо помітним у часи незалежної України, нерідко викликають нерозуміння в середовищі більш традиційних вірян. Полеміка щодо того, яка музика має право лунати під час богослужінь, велася як на початку протестантського руху, так і ведеться дотепер, і не лише серед баптистів, бо однією з фундаментальних рис протестантизму є свобода розуміння та трактовки духовних істин, серед яких питання про те, як правильно поклонятися Богові. Відомий американський музикознавець, диригент, великий друг українських християнських музикантів, директор організації «Музика в світовій культурі» Стів Бенхам писав так: «Музика є основним шляхом поклоніння Богові. Музика в церкві значно сприяє нашому вираженню похвали та палкої любові Богу, а також допомагає виразити власне вчення і теологічні погляди. Тобто музика відіграє роль богослужіння, учнівства та євангелізації в церкві» [14].

Духовна музика сучасних протестантських громад в Україні та у всьому світі вирізняється неймовірним розмаїттям жанрів та стилів. Музичний супровід протестантських богослужінь охоплює широкий діапазон - від стриманого хорового чи общинного співу a cappella до гучного звучання симфонічних оркестрів. Поряд із хоралами Лютера лунають естрадні обробки популярних американських пісень, а кантати Баха чи хорові концерти українських класиків чергуються зі жвавими ритмами джазових церковних колективів. Усе це відбувається під єдиним гаслом - Soli deo Gloria! 


\section{СПИСОК ЛІТЕРАТУРИ}

1. Бондар І. Особливості прояву духовної традиції лютеранствав музичному мистецтві Західної Європи. Актуальні проблеми теорії, історії та практики художньої культури: зб. наук. праць, вип. XXVIII. Київ : Міленіум, 2012. С. 9-16.

2. Васюріна А.О. Музика у світових релігіях: особливості вияву. Світогляд - Філософія - Релігія : зб. наук. праць. Суми: УАБС НБУ, 2012. Вип. 2. С. 140-151.

3. Гончаренко Е.С. Музыкальные реформы М. Лютера и их следы в реформаторской деятельности И.С. Проханова. Богословские размышления. Реформация: восточноевропейские измерения. Евроазиатская аккредитационная ассоциация, 2016. Т. 17. С. 260-266.

4. Ефимова Н.И. Раннехристианское пение в западной Европе VIII-X столетий: к проблеме эволюции модальной системы средневековья. Москва : МГУ, 2004. 277 с.

5. Історія музики: від витоків до сучасності [Я. Бодак, Ю. Казакевич, Д. Джензен]. Луцьк : РТ МКФ Християнське життя, 2015. Ч. $1.312 \mathrm{c}$.

6. История музыки: Мартин Лютер и протестантский хорал. URL: https://iskusstvo-zvuka.livejournal.com/120535.html (дата звернення 10.02.2021).

7. Кадочников В. Музыка протестантских церквей в поисках образа Христа. URL: http://www.center-logos.ru/index. php/2009-10-10 (дата звернення 12.02.2021).

8. Карцовник В.Г. Григорианское пение. Православная энциклопедия. Москва : Церковно-научный центр «Православная энциклопедия», 2006. Т. 9. с. 461-471.

9. Лебедев С. Н. Григорианский хорал. Большая российская энциклопедия. Москва : Большая российская энциклопедия, 2007. T. 7. C. $746-748$.

10. Мартин Лютер и церковная музыка. URL: http://adventism.pro/ church/martin-lyuter-i-tserkovnaya-muzyka/ (дата звернення 11.02.2021).

11. Протестантизм в Україні - його основні положення та напрямки. URL : https://ru.osvita.ua/vnz/reports/relig/21285/ (дата звернення 06.02.2021).

12. Проханов И.С. Предисловие. Гусли: сборник духовных песен $c$ нотами. Лодзь : Книгоиздательство Компас, 1928. 826 с.

13. Розеншильд К.К. История зарубежной музыки. До середины XVIII века: учеб. пособие. Москва : Музыка, 1978. Вып. 1. 544 с.

14. Романенко O. Реформація і музика. URL : https://www.baptyst. com/reformatsiya-i-muzyka/ (дата звернення 11.02.2021).

15. Спис О. Сучасна протестантська пісенно-музична творчість як форма служіння: проблеми і виклики. Релігія та соиіум. 2011. № 1. С. $160-166$.

16. Уилсон-Диксон Э. История христианской музыки [пер. с англ.]. Санкт-Петербург : Мирт, 2001. 428 с. 
17. Хоружий Г. Протестантизм як результат європейської Реформації. Вісник Київського національного торговельно-економічного університету. Київ, 2017. № 2. С. 105-119.

18. Черенков М. Протестантская теология и философия религии: встречи на границах иного. URL: http://www.religion.in.ua/main/ bogoslovya/11710-protestantskaya-teologiya-i-filosofiya-religii-vstrechina-granicax-inogo.html (дата звернення 11.02.2021).

19. Ярош О. Протестантська сакральна музика: духовні основи i витоки формування традиції. Гілея: науковий вісник. 2016. Вип. 107. C. 209-212.

20. Luther (nach einer Hörernachschrift der Woche Predigtam am 1.8.1528), zit.n. Mühlhaupt, 1961. P. 544-560.

\section{REFERENCES}

1. Bondar I. (2012). Osoblivosti proyavu duhovnoyi traditsiyi lyuteranstva $\mathrm{v}$ muzichnomu mistetstvi Zahidnoyi Evropi. Aktualni problemi teoriyi, istoriyi ta praktiki hudozhnoyi kulturi: [zb. nauk. prats, vip. XXVIII]. K.: Milenium [in Ukrainian].

2. Vasyurina A. (2012). Muzyka u svitovikh relihiyakh: osoblyvosti vyyavy. Svhtoglyad - FHlosofнya - Relнghyа: zb. nauk. prats'. Sumi [in Ukrainian].

3. Honcharenko E. (2016) Muzycalnie reformy M. Lyutera i yikh sledy $v$ reformators'koyi diyal'nosti I. S. Prokhanova [in Russian].

4. Yefimova N. (2004). Rannekhristianskoye peniye v zapadnoy Yevrope VIII-X stoletiy: problema evolyutsii modal'noy sistemy srednevekov'ya. Moskva: MGU [in Russian].

5. Istoriya muzyky: vid vitokiv do suchasnosti (2015). Y. Bodak, Y. Kazakevych, D. Dzhenzen. Luts'k: RT MKF Khrystyyans'ke zhyttya [in Ukrainian].

6. Istoriya muzyky: Martin Lyuter i protestant·s'kyy khoral. URL : https://iskusstvo-zvuka.livejournal.com/120535.html [in Russian].

7. Kadochnykov V. Muzyka protestant $\cdot \mathrm{s}^{\prime} \mathrm{kykht}$ serkvey v poiskah obraza Khrysta. URL: http://www.center-logos.ru/index.php/2009-10-10 [in Russian].

8. Kartsovnik V. H. (2006). Grigorianskoye peniye. Pravoslavnaya entsiklopediya. Moskva [in Russian].

9. Lebedyev S. N. (2007). Hryhorians'kyy khoral. Velykarosiys'kaya entsyklopediya [in Russian].

10. Martin Lyuter i tserkovnaya muzyka. URL : http://adventism.pro/ church/martin-lyuter-i-tserkovnaya-muzyka/ [in Russian].

11. Protestantyzm v Ukrayini - yogo osnovni polozhennya ta napryamky. URL : https://ru.osvita.ua/vnz/reports/relig/21285/ [in Ukrainian].

12. Prokhanov I. S. (1928). Predislovie // Dukhovnie pesni s notamy. L: VSEH [in Russian].

13. Rozenshyl'd K. Bakh. Kantaty. URL : https://www.belcanto.ru/ bach_kantaten.html [in Russian]. 
14. Romanenko O. Reformatsiya i muzyka. https://www.baptyst.com/ reformatsiya-i-muzyka/ [in Ukrainian].

15. Spys O. (2011). Suchasna protestant-s'ka pisenno-muzychna tvorchist' yak forma Sluzhinnya: problemy i vyklyky. Relihiya ta sotsium [in Ukrainian].

16. Uilson-Dikson E. (2001). Istoriya hristianskoj muzyky [per. s anhl]. Sankt-Peterburh: Myrt [in Russian].

17. Khoruzhyy H. (2017). Protestantyzm yak rezul'tat yevropeys'koyi Reformatsiyi. Visnyk Kyyivs'koho natsional'noho torhovel'no-ekonomichnoho universytetu [in Ukrainian].

18. Cherenkov M. Protestantskaya teologiya i filosofiya religii: vstrechi na granitsakh inogo URL : http://www.religion.in.ua/main/bogoslovya/11710-protestantskaya-teologiya-i-filosofiya-religii-vstrechi-na-granicax-inogo.html [in Russian].

19. Yarosh O. (2016). Protestant·s'ka sakral'na muzyka: dukhovni osnovy i vytoky formuvannya tradytsiyi. Hileya: naukovyy visnyk, Vyp. 107 [in Ukrainian].

20. Luther M. (1961). Nach einer Hörernachschrift der Woche Predigtam am 1.8.1528), zit.n. Mühlhaupt [in German]. 